\title{
Government Ownership and Trusteeship of Water
}

Frank J. Trelease*

A recent issue of the Harvard Law Review carried an article with the strange title of "Tu-tu." This eye-catching title leads the reader to a fable about a tribe of south-sea islanders who have a tabu against having anything to do with one's mother-in-law. It appears that if one of these islanders accidentally encounters his mother-in-law, he becoines what is called "tu-tu" and is subject to some dangerous force or infection which attaches to hin and threatens the whole commumity with disaster. For this reason a person who has become tu-tu must be subjected to a special ceremony of purification.

Civilized Americans, of course, know that there is no such thing as tu-tu. As the prevalence of mother-in-law jokes testifies, ${ }^{2}$ people encounter their mothers-in-law often and nothing like this happens. Therefore, tu-tu does not exist in fact, it has no reference to reality. While it might be argued that tu-tu has reality to the islanders, it can be demonstrated that even they can get along very well without the concept. They say "If a man encounters his mother-in-law, he becones tu-tu. When a man is tu-tu, he inust be purified." But all reference to tu-tu may be eliminated and the same result reached by simply saying "If a man encounters his mother-in-law he must be purified."

The reader will think, this is all very amusing, but what is it doing in the Harvard Law Review? Reading further, he will find an exploration of the semantics of legal reasoning, an investigation of the meaning of legal phrases, pointing out that many of them have no more reference to any actual thing in existence than does tu-tu.

An examination of the legal concept of ownership shows that it falls into this pattern. "I bought this watch, therefore I have ownership of it. I have ownership of this watch, therefore I may recover it from one who takes it from me." Just as we eliminated tu-tu, we can eliminate the middle concept entirely: "I bought this watch, therefore I may recover it from one who takes it from me." The author suggests that we inay substitute "tu-tu" for "ownership," or, if we prefer, "green cheese," and the logic is unimpaired.

This is somewhat disturbing. No natter how carefully we follow the argument, nod our heads, and say "Ownership is nothing, it does not exist,

* Professor of Law, University of Wyoming.

${ }^{1}$ Ross, Tib-tu, to HARv. L. Rev, 812 (1957).

2 To add another, some may think there is merit to such a tabu. 
it is tu-tu," we feel that someone is pulling our leg, playing with words. We know we "own" our watches, lawyers deal with the ownership of property every day of their hives, use the word in the law constantly. But what this exercise in semantics shows is that ownership is not a thing in itself, but a convenient word tool used to express a number of ideas. We can get along without it, by saying that if I buy a watch I can recover its possession, but if we drop the word "ownership" from our vocabularies, our rules would become quite complex. We would have to say the same thing about a watch that was given to me, that I inherited, that I found, and so forth. To avoid this, "ownership" has a useful function im serving as a collective expression of all the fact situations that give a person the power to recover a watch taken from him. The word is also used in what is really a quite different sense. If I bought the watch, I can not only recover its possession, I can get damages for its detention, I can give it way, I can sell it, my next of kin will inherit it, etc. So again, it is convenient to use "ownership" to refer to all of these legal consequences of buying a watch. The word becomes a convenient connecting link between many different fact situations and all of the legal consequences of each of those facts. But it must be remembered that ownership is not itself a thing, it is not a fact. It is a useful device, a vessel into which we may put many things, but it has no independent meaning aside from that which we put into it.

This paper is an exploration of what is meant by "ownership" of water. For years the constitutions and statutes of western states have declared that the water of the western streams is owned by the public, or by the state. Various patterns of water regulation have been built upon this concept. Yet there have long existed suggestions that the federal government owned the waters of the West, and recently the possibility of a federal title, dispossessing that of the state, has caused grave concern throughout the West and given rise to fears that the structure of regulation built upon state ownership may be tottering. ${ }^{3}$ Quite recently the Supreme Court of California, in the Ivanhoe case, ${ }^{4}$ injected a new idea that is similarly disturbing - that the state's ownership of the water is impressed with a trust. The superimposing of the trust concept upon the state ownership concept has given rise to all sorts of questions as to the extent of change that may result from applying trust principles to water law. Perhaps we can find a way out of these puzzles by using a little semantics to clarify our thoughts, perhaps at least we may be able to better understand the nature of the problems presented by the puzzles, and though we may not be able to solve them immediately, we may at least be able to better prepare ourselves for their ultimate solution.

${ }^{3}$ See, e.g., FPC v. Oregon, 349 U.S. 435 (1955).

4 Ivanhoe Irrigation Dist. v. All Parties, 47 Cal. 2d 597, 306 P.2d 824 (1957), appeal filed, (U.S.) May 13, 1957. 


\section{CONCEPTS OF "OWNERSHIP" OF WATER}

Some concepts of water or stream ownership are quite old, and an elaborate classification of them has been constructed. Water, as a thing in its natural habitat, was variously conceived by the Romans to be res mullius, the property of no one, along with the air, the sea, and wild animals, or as res communes, common things owned by everyone. Like a fish, a bird, or a wild animal, the corpus of water is capable of being owned only by one who takes it into his possession by appropriating it or capturing it from the source..$^{5}$

Yet private rights to the use of water in a stream may be obtained. These private usufructuary rights, like other property, exist by virtue of and are subject to the law of the place where the stream is located. The state has power over such private rights in water, power in the sense of sovereignty or imperium, the general power to dictate the laws of property and to regulate its use. ${ }^{\mathfrak{B}}$ In addition there are rights in some waters that are public rather than private rights. These include rights of navigation, of access to navigable waters, and to fish in navigable waters.

As for navigable waters, to which public rights attach, the idea early grew that the stream itself belonged to the public, and that the state is the representative of the public to enforce the public interest. These streams are classed as publici juris, belonging to the public.?

In non-navigable streams to which private usufructuary rights obtain, it cannot be said that a riparian owner or an appropriator owns the stream, or a part of it, or that all of the riparian owners or appropriators own the stream in common. Their rights are usufructuary, not possessory. But even in these waters, the state has more than imperium, the right to regulate in furtherance of the police power. For certain purposes the state as a representative of the interests of the public has the power to protect the stream from destruction at the hands of the riparian proprietors. ${ }^{8}$ Perhaps to this extent, even these non-navigable "private" streams could be said to be publici juris.

There is a further extension of these property notions, to res publicae, things that belong to the state as a corporate entity, like the state capitol building. These the state holds as a proprietor, by analogy to the individual holder of private property. ${ }^{9}$

\footnotetext{
51 Wiex, Water Rights in the Western States 3 (3d ed. 1911).

6 Lasky, From Prior Appropriation to Economic Distribution of Water, 1 Rocrx MT. L. REv. 161, 172 (1929).

7 Id. at $176,187$.

${ }^{8}$ Hudson County Water Co. v. McCarter, 209 U.S. 349 (1908).

${ }^{\theta}$ Lasky, From Prior Appropriation to Economic Distribution of Water, 1 Rocrx Mr. L. REv. 161, 186-87 (1929).
} 
This Latin nomenclature is often applied to the concepts expressed by the constitutional and statutory declaration of state and public ownership in the West. But in the arid and semi-arid "Great American Desert" to which the pioneers came, it was immediately apparent that a new concept of a stream was needed. In the East, streams were thought of as things with a continuous existence, and not only must the state act to preserve the stream from destruction at private hands, but the state itself might not destroy the stream, and must preserve it for the use of the public and the riparian proprietors. ${ }^{10}$ In the West it was seen that water must be consumed, that the streams must be diverted from their courses, even destroyed, if man was to survive there. The new thought grew up, never very clearly expressed, of a stream as a source from which consumers might draw. While under the doctrine of prior appropriation the use of the water was made the subject of private rights, all persons were given the privilege of acquiring such rights. All streams were made subject to this public privilege, whether navigable or not. Thus publici juris took on a new and wider meaning.

Arizona was the first to enact the concept of state or public ownership of water into law. In the statutory bill of rights adopted when Arizona became a territory in 1864 , it was declared that all streams, lakes, and ponds capable of being used for navigation or irrigation are public property, and in the "Howell Code" of laws it was further declared that all running waters are public and applicable to the purposes of irrigation and mining. ${ }^{11}$ Colorado was the first state to place the concept in its highest law. Though the constitutional convention rejected a statement of absolute ownership by the state of all waters, the constitution as adopted declared the waters of every natural stream, not previously appropriated, to be the property of the public, dedicated to the use of the people of the state. ${ }^{12}$ Wyoming was the first state to come out flatly with a theory of res publicae, her constitution declaring the water of all natural streams to be the property of the state. ${ }^{13}$ Some variant of this concept has been adopted in all of the seventeen western states by constitution or statute, although Montana's weak declaration that the use of appropriated water is a public use had to be strengthened by court decision into a full declaration of state title, ${ }^{14}$ and although Oklahoma's law was repealed, apparently inadvertently, when it was left out of a compilation of statutes. ${ }^{15}$

\footnotetext{
101 Farnitam, WATERS aNd WATER Rights 598-600 (1904).

11 ARIz. Comrp. Laws 1864-1871, art. 22, p. 25 ; ARIz. Code (Howell 1864) c. 55, §§ 1, 3.

12 Coro. Const. art. XVI, $\$ 5$.

13 Wyo. Const. art. $8, \S 1$.

14 Mont. Const. art. III, § 15; Smith v. Denniff, 23 Mont. 65, 57 Pac. 557 (1899), rev'd on rehearing, 24 Mont. 20, 60 Pac. 398 (1900).

15 Otra. Cosmp. Laws 1909, $\$ 3915$, omitted from OrIA. Rev. Laws (1910) and thereby repealed.
} 
On a careful reading, these statutory and constitutional provisions seem to differ both as to who is the owner and as to what is owned. In Wyoming, Montana, Idaho, North Dakota, and Texas the water is declared to be the property of the state, ${ }^{16}$ in California the property of the people of the state. ${ }^{17}$ In Arizona, Colorado, Nebraska, Nevada, New Mexico, South Dakota, Oregon, Utah, and Washington, ${ }^{18}$ the waters are the property of the public. Kansas, with the newest declaration, seems to have the weakest of all, merely dedicating all waters to the use of the people of the state. ${ }^{10}$ In $\mathrm{Ne}$ braska the constitution dedicates the use of the water to the people of the state, though the statutes declare the water to be the property of the public. ${ }^{20}$ In most of these states the declaration relates to all waters (at least those in watercourses), but in Colorado, New Mexico, and formerly Oklahoma the declaration was limited to the unappropriated water. ${ }^{21}$

If real differences were intended by the framers of these varying statements, the courts have failed to find them and have blurred the distinctions. Although there seems to be clear evidence that the Colorado constitutional convention shied away from an outright statement of state proprietorship and compromised on a statement of public ownership, ${ }^{22}$ the courts of that state have sometimes held that the constitution is simply declaratory of the old publici juris concept and in other cases liave claimed it creates a state proprietorship like that expressed in Wyoming's constitution. ${ }^{23}$ On the other hand, although it seems undemiable that the draftsmen and proponents of Wyoming's constitution intended state proprietorship in its strictest sense, ${ }^{24}$ the courts have said that the constitution declares and confirms the already existing principle of publici juris, and have stated that the public ownership is rather that of sovereign than of proprietor, and have further equated the terms the public and the state. ${ }^{25}$ In Nebraslia the court has said, without

16 Wyo. Const. art. 8, $\$ 1$; note 14 supra; IDAHo Code ANv. $\$ 42-101$ (1948) ; N.D. Const. § 210; Tex. Rev. Crv. Stat. art. 7467 (1948).

17 Cat. Water CODE $\$ 102$.

18 Artz. Rev. Stat. \$ 45-101 (1956) ; Colo. Const. art. XVI, § 5; Neb. Rev. Stat. 46-202 (1952); Nev. Comp. Laws $\S 7890$ (1929); N.M. Const. art. XVI, § 2; S.D. CodE $\S 61.0101$ (1939); Ore. Rev. Stat. \$537.110 (1953); UtaH Code § 73-1-1 (1953); Wast. Rev. Code $\S 90.04 .020$ (1951).

19 Kan. Gen. Stat. Anv. \$ 82a-702 (1949).

20 NEB. Const. art. XV, § 6; Neb. ReV. Stat. § 46-202 (1952).

21 Notes $12,15,18$ supra.

22 Lasky, From Prior Appropriation to Economic Distribution of Water, 1 RockY MT. L. REv. 161, 175 (1929).

23 See. e.g., Bowers v. McFadzean, 82 Colo. 138, 257 Pac. 361 (1927) ; Stockman v. Leddy, 55 Colo. 24, 129 Pac. 220 (1912); Wyatt v. Larimer \& Weld Irrigation Co., 1 Colo. App. 480, 29 Pac. 906 (1892).

24. Lasky, From Prior Appropriation to Economic Distribution of Water, 1 Rockx MT. L. REv. 161, 176-77 (1929).

25 Willey v. Decker, 11 Wyo. 496, 73 Pac. 210 (1903); Farm Inv. Co. v. Carpenter, 9 Wyo. 110, 61 Pac. 258 (1900). 
taking a breath, that water is publici juris, that its use belongs to the public, that its use is controlled by the state in a sovereign capacity, and that the state has a proprietary interest, all without any understanding that it is saying different and inconsistent things rather than simply redundantly paraphrasing the same concept. ${ }^{26}$ In a Utah case, the court reverted all the way back to res communes. ${ }^{27}$

Nor has any significance ever been given to the difference between a declaration that the state ownership attaches to the unappropriated waters of the streams rather than to all of the waters. In both Colorado and New Mexico, where the more restricted form of statement is used, the courts have asserted state ownership of all of the waters. The Colorado court has said that the state not only has a right to ownership but the unrestrained right, within its own boundaries, to distribute its waters to those who have under its authority acquired by appropriation the right to their use. ${ }^{28}$ This is a clear claim to ownership of the appropriated water. In a very recent New Mexico case ${ }^{29}$ the court claims all of the water within the state for the state and says that the state merely authorizes its use by appropriators. This too is an extension of ownership to waters that go to supply existing appropriations.

II

\section{SIGNIFICANCE OF STATE "OWNERSHIP"}

So far, this paper has been simply an examination of words used, without any indication of their significance, or of the uses to which the concept of state ownership has been put, or to the results obtained by its use and the legal consequences said to follow. First, as might be expected, the theory has been used in interstate relations. The expenditure of state funds for a committee to investigate the activities of the national government with reference to Colorado water resources, and claims made by other states to streams originating in Colorado, has been upheld on the theory that the state was spending its money simply to protect its own property..$^{30}$

A second use of the ownership doctrine is found in situations where the state interests are aligned against the interests of a citizen or water user of the state. The power of state water authorities to issue a permit for an appropriation subject to conditions inposed in the public interest has been based upon the premise that the state has such a proprietary interest in the running water of the streams that it may transfer a qualified ownership of

28 Kirk v. State Bd. of Irrigation, 90 Neb. 627, 134 N.W. 167 (1912).

${ }^{27}$ Adams v. Portage Irrigation, Reservoir \& Power Co., 95 Utah 1, 72 P.2d 648 (1937).

28 Stockman v. Leddy, 55 Colo. 24, 129 Pac. 220 (1912); see also Wheeler v. Northern Colo. Irrigation Co., 10 Colo. 582, 17 Pac. 487 (1887).

20 State ex rel. Erickson v. McLean, 308 P.2d 983 (N.M. 1957).

30 Stockman v. Leddy, 55 Colo. 24, 129 Pac. 220 (1912). 
the right to use them. ${ }^{31}$ The whole permit system of initiating appropriations has been said to be based on a theory of permissive use of state property. ${ }^{32}$ In proceedings to declare the forfeiture of an appropriation for an artesian well which had been allowed to run to waste, a decision upholding the forfeiture has been said to rest upon the premise that the state as the owner of the water has the right to prescribe how it may be used..$^{33}$

The concept of state ownership has also appeared in many cases involving disputes between citizens. Adjudication proceedings, in which the rights of all users of a stream are adjusted and declared, have been said to be mere distributions of the state's water.$^{34}$ Conflicting claims to the ownership of a water right have been resolved by tracing a chain of title stretching back to the state. ${ }^{35}$ The state property in water, with a corresponding right to prescribe how it may be used, has been made the basis of an adjustment between appropriators, one claiming that the other's right had been abandoned or forfeited..$^{36}$ That adverse use does not run against the state has been given as the reason a water right cannot be acquired by prescription. ${ }^{37}$ A royalty charged by a public utility distributing water, over and above the reasonable charges for water rent, has been held unlawful since the water was the property of the state for which the utility might not charge. ${ }^{38}$

What clues do these cases give us as to the meaning of state ownership? Frrst, notice that each of these results could be accomplished without the concept of state ownership. As for interstate rights, the United States Supreme Court has on numerous occasions apportioned the waters of interstate rivers among states without reference to state stream ownership, using instead concepts of sovereignty or parens patriae. ${ }^{30}$ The state's power to adjudicate the rights of appropriators and distribute the water among them. has been explained on the basis of police power, as the Nebraska court has said, ". . . in the furtherance of a wise public policy to afford an economical and speedy remedy for those whose rights are wrongfully disregarded by others, as well as to prevent unnecessary waste and useless diminution of the waters of streams . ..." Similarly the permit system and forfeiture statutes have been based upon police powers. ${ }^{41}$ The case involving the roy-

\footnotetext{
31 Kirk v. State Bd. of Irrigation, 90 Neb. 627, 134 N.W. 167 (1912).

32 Wyoming Hereford Ranch v. Hammond Packing Co., 33 Wyo. 14, 236 Pac. 764 (1925).

33 State ex rel. Erickson v. McLean, 308 P.2d 983 (N.M. 1957).

34 Farm Inv. Co. v. Carpenter, 9 Wyo. 110, 61 Pac. 258 (1900).

35 Bowers v. McFadzean, 82 Colo. 138, 257 Pac. 361 (1927).

36 In re Manse Spring, 60 Nev. 280, 108 P.2d 311 (1940).

37 Mountain Meadow Ditch and Irrigation Co. v. Park Ditch and Reservoir Co., 130 Colo. 537, 277 P.2d 527 (1954).

38 Wheeler v. Northern Colo. Irrigation Co., 10 Colo. 582, 17 Pac. 487 (1888).

39 E.g., Hinderlider v. La Plata River \& Cherry Creek Ditch Co., 304 U.S. 92 (1938);

Wyoming v. Colorado, 259 U.S. 419 (1922); Kansas v. Colorado, 206 U.S. 46 (1907).

40 State ex rel. Cary v. Cochran, 138 Neb. 163, 168, 292 N.W. 239, 244 (1940).

41 Wyoming Hereford Ranch v. Hammond Packing Co, 33 Wyo. 14, 236 Pac. 764 (1925).
} 
alty payment for water ${ }^{42}$ could have been decided on ordinary principles of public utility law. If, therefore, other concepts can be substituted for state ownership is this not like the substitution of "green cheese" for "tu-tu"? And if substitutions can be made, can we not eliminate the middle term altogether? Why is it better to say "The state owns the water, therefore it may regulate its use" instead of "The state may regulate the use of water?"

III

\section{"TRUSTEESHIP" OF WATER}

Before attempting to answer let us first look at the "trust theory" of water ownership. In the Ivanhoe case, the California court, after reviewing the statutory basis of state ownership, and the trust relation said to exist between an irrigation district and the consumers of its water, stated: ${ }^{43}$

Likewise the state is not the owner of the domestic water of the state in the sense that it has absolute power and dominion over it to the exclusion of the rights of those who have the beneficial interest therein. The title is an equitable one residing in the water users of the state. The state as an entity is the holder of the legal title as trustee for the benefit of the people of the state, all of whom in the last analysis, are the water users of the state .... As trustee, the state and its agencies ... are bound faithfully to admimister that trust and are answerable to the courts, in the exercise of their traditional powers in equity, for the proper discharge of their stewardship. They must administer it consistently with and not in violation of the rights of the beneficiaries.

This injects into the picture concepts new to Califorma, concepts that disturbed the dissenting judges, who called this "trust theory" unsound, a serious obstacle, the ramifications of which are infinite, technical, and unpredictable, and a handicap to the future developnient of the water resources of the state. ${ }^{44}$

Actually, the concept is quite old. Public and state ownership of the beds of navigable streams, comparable to the ownership of the land upon which the statehouse sits, has long been with us. It was in this connection that the idea of a public ownership held in trust for the menibers of the general public came into being. Restrictions were placed on the power to convey these stream beds, ranging from requirements that conveyances be for uses not inconsistent with the public interests, to complete barriers against permanent alienation of the bed..$^{45}$ These restrictions were expressed by the phrase, "the state owns the beds in trust for the public."

42 See note 38 supra and text corresponding thereto.

43 Ivanhoe Irrigation Dist. v. All Parties, 47 Cal. 2d 597, 625, 306 P.2d 824, 840-41 (1957).

44 Id. at 648,306 P.2d at 855 .

45 1 farneass, Waters and Water Rights 172 (1904); 1 Powell, Real Property 620 (1956). 
Nor is the idea new as applied to the public ownership of water. In fact, some of the western constitutions and statutes that declare public ownership incorporate the idea of a trust relationship, by "dedicating" the water "to the use of the people," as in Colorado, Kansas, and Nebraska. ${ }^{40}$ The courts of Wyoming, Texas, and New Mexico long ago added the trust statement to the usual state ownership. ${ }^{47}$

As in the case of state ormership, state trusteeship has not played a really significant role in developing or shaping the law of water rights. In Wyoming, the phrase first appeared as an offhand quotation from Kent: "The Sovereign is trustee for the public," but the court did not use the thought in reaching its decision, ${ }^{48}$ and has been explaining or apologizing for the phrase ever since. In Willey v. Decker, ${ }^{40}$ the court held that the state ormership of the water in trust did not prevent an appropriation by diversion from a stream in Wyoming for use on lands situated in Montana, and in Merrill v. Bishop, ${ }^{50}$ where the court was asserting state control over water rights on allotted Indian lands by deriving a title in the state from an original federal title, it felt constrained to say that the state title was good notwithstanding that it holds the property "merely as trustee for the public and not in a proprietary capacity.'151 In Texas, the supreme court has defined the trust in some detail and classified its beneficiaries. Navigable waters are said to be held in trust first, for navigation purposes; second, the "riparian" waters - those needed by riparian owners-are held in trust for the riparian owners; third, the "nonriparian" waters are to be controlled and disposed of by the people for the best interests of all the people subject to appropriation under state law; and fourth, the waters are held in trust "for uses and benefits not here involved." 52 By developing this line of reasoning, Texas has resolved conflicting claims of riparians and appropriators by giving the riparians the better right to waters below the line of highest ordinary flow, and appropriators the rights to flood or storm waters. At one time the Califonia courts approached a similar result, without the use of the trust theory. ${ }^{53}$ Texas courts have also used trust concepts to reach decisions that an appropriator could not claim his waste waters after they had once been used, ${ }^{54}$ and that the state might enjoin the pollution of

\footnotetext{
46 Notes 18,19 supra.

47 State ex rel. Bliss v. Dority, 55 N.M. 12, 225 P.2d 1007 (1950) ; Motl v. Boyd, 116 Tex

82, 286 S.W. 458 (1926); Willey v. Decker, 11 Wyo. 496, 73 Pac. 210 (1903).

48 Farm Inv. Co. v. Carpenter, 9 Wyo. 110, 139, 61 Pac. 258, 265 (1900).

4011 Wyo. 496, 73 Pac. 210 (1903).

5074 Wyo. 298, 287 P.2d 620 (1955).

51 Id. at 312,287 P.2d at 625 .

52 Motl v. Boyd, 116 Tex. 82, 111, 286 S.W. 458, 468 (1926).

53 See Fifield v. Spring Valley Water Works, $130 \mathrm{Cal}$. 552, 62 Pac. 1054 (1900), overruled in Miller \& Lux v. Madera Canal \& Irrigation Co., 155 Cal. 59, 99 Pac. 502 (1909).

54 South Texas Water Co. v. Bieri, 247 S.W.2d 268 (Tex. Civ. App. 1952).
} 
streams. ${ }^{55}$ New $\mathbb{M}$ Mexico, in a fairly recent case, reasoned that the state's status as trustee gave it the authority to institute suits to protect the public against unlawful uses, ${ }^{56}$ but this power of the state has been recognized elsewhere without resort to any concept of trust law..$^{67}$

In the Ivanhoe case, the court states the trust theory of state ownership, then quotes section 8 of the Reclamation Act, ${ }^{58}$ providing that nothing in that act is to affect or interfere with the laws of any state, relating to the control, appropriation, use or distribution of water, and that the Secretary of the Interior is to proceed in conformity with such laws. Since the federal government has recognized that the law of the state is determinative of rights to water in the state, it is argued that in all transactions between the state and the United States the parties are dealing with trust property, held by the state or by those who have acquired rights to it for the benefit of the real owners of the property, who are the present and prospective water users. Whatever interest or title the United States has acquired to water by appropriation, assignment, or otherwise is subject to this limitation of title. The trust gives to each landowner an inchoate right to the use of water upon any or all of his lands, and to deprive him of this right is said to violate the due process clause and the equal protection of the laws.

Shortened up a bit, the argument is that the United States must proceed in conformity with state law, that under those laws the state holds the water in trust in favor of irrigators, not limited in the amount of land for which water inay be appropriated, that therefore the United States may not impose such a limit. But notice that we can treat "trust" as we did "tu-tu": the result can be as logically reached without inention of a trust. It can be said simply that the United States must proceed in conformity with state law, that under that law there is no limit on the amount of land for which water may be appropriated, that therefore the United States may not impose such a limit. The trust theory does not dictate the result, the result can be reached without it.

As was said, this trust theory disturbed the three dissenting judges. Justices Gibson and Traynor say that it involves the problem of applying settled trust principles to all water rights in the state, a problem that will be attended by much uncertainty and difficulty. ${ }^{58}$ How is the rule that all water users of the state have equal rights as beneficiaries of the trust to be squared with the doctrine of appropriation? Justice Carter, in addition to noticing that the priority doctrine will deprive some of the beneficiaries of

55 Goldsmith \& Powell v. State, 159 S.W.2d 534 (Tex. Civ. App. 1942).

56 State ex rel. Bliss v. Dority, 55 N.M. 12, 225 P.2d 1007 (1950).

57 State v. Birdwood Irrigation Dist., 154 Neb. 52, 46 N.W.2d 884 (1951); State v. Hiber, 48 Wyo. 172,44 P.2d 1005 (1935).

ES 45 Stat. 1065 (1928), 43 U.S.C. \$617q (1952).

$5947 \mathrm{Cal} .2 \mathrm{~d}$ at 665,306 P.2d at 859 . 
the trust of their share of the trust res, notes that the terms of the trust seem indefinite and uncertain, for if they are to be found in the statutes, they will change from time to him as the statutes are amended and construed. ${ }^{60}$

Are these fears well founded? Will California lawyers and judges be turning to Scott on Trusts and Bogert on Trusts to seek the solutions to future water law problems? A glance at the tables of contents of those works will show the absurdity of such a notion. If the waters of New Mexico and Wyoming are held in trust and have been so held all these years, with no worse results than the present water laws of those states indicate, California has little to fear. The trust concept has served its purpose for the moment, it has served to forcibly present a position taken by the court and to express an idea. The court feels that the 160-acre limitation, or rather the excess land limitation, is an unwonted federal restriction upon the right of California citizens to use the waters of the state of California; they feel it is the prerogative of the state to say how much California land may be watered by the streams that flow in the state. To communicate this idea, the court uses as an assertion that which is really an analogy. They could have said, the relation of the states to its water users is like a trust, but to put across the thought more forcefully, they said it is a trust. But there is no doubt in my mind that in the next water rights case to reach them, a case not involving a conflict between state interests and national interests, the expression that served so well in the Ivanhoe case will not be permitted to interfere with well-settled principles of water law.

Quotations from "Alice in Wonderland" are no longer fashionable, but one is so apt here as to be irresistible. When Alice protested to Humpty Dumpty that "glory" does not mean "a nice knock-down argument," Humpty scornfully replied, "When $I$ use a word, it means just what I choose it to mean-neither more nor less. The question is, which is to be masterthat's all."

Here hes the danger-that we may let the words become our masters. If we are the masters, so that the words mean what we want them to mean, we are all right. State ownership means that the state has power to control the allocation of water rights by permits, that the state may adjudicate rights among appropriators, that it may take an active part in seeing that the water laws are obeyed, and that it may enact forfeiture laws. Why does it mean this? Because we use the words to express the complex of these legal consequences of the fact that the state is the organization set up to regulate and control the allocation of scarce things among the people. State trusteeship means that in so allocating waters, the state authorities must act in the public interest. The public interest may require equal participation by all the people, as in the case of navigation, or it may demand the assign-

6047 Cal.2d at 675,306 P.2d at 871. 
ing of individual property rights to appropriators or to riparians, as in the case of irrigation.

On the other hand, if we ascribe to the word some independent meaning of its own, if we use the middle term as a starting point, we are in trouble. The word has beconie the master. If we were to say, "Ownership of property gives the right to do with it as the owner pleases," and reason from there, we would reach all sorts of absurd results. If we say, "The state owns the water and merely permits its use, therefore it may withdraw its permission at will," all appropriators and riparians will cry that due process is violated. If we say, "All trusts are subject to the rule that the beneficiary nray not sue to protect his interest unless the trustee fails to act," then no California water user may sue another without first demanding that the Attorney General bring the suit for him.

As I have said, we are not too likely to do these things, but sometimes words do obscure our thoughts. California lawyers and judges must be on their guard against this type of thinking, and should not jump to too many conclusions by trying to apply trust principles to water cases.

IV

STATE VS. FEDERAI "OWNERSHIP" OF WATER

There is another field in which this type of thinking has recently come to the fore, with similar dangers. This is in the area of state and federal conflict over the control of water use on the public doniain. Many people are thinking that this problem should be decided on the basis of who "owns" the water, building their arguments on the premise that the federal government owns the water, or that the state owns the water. But these premises are not bedrock upon which a logical structure can be erected, they are shifting sands.

The nature of state ownership has been explored, and an examination of the federal title is now in order. When the United States acquired from France and Mexico the territory from which has been formed the western states, less than three per cent of the ceded land was in private ownership. ${ }^{61}$ As to all the rest, the management of the public domain certainly proceeded along the lines of a basic theme that the United States owned all of the unappropriated public domain in the same sense that an individual owns a farm. The United States as an entity, under the property clause of the Constitution, ${ }^{82}$ was regarded as having the capacity to hold, acquire, and transfer this land as the owner.

However, when we say that the United States is the owner of the public domain, we give no power to the government by so saying. We are simply

611 Powell, Rear Property 644 (1956).

62 U.S. CoNsr, art. IV, \&3. 
using the word "owner" to express a complex of powers that we already have in mind. We mean something quite different from what we mean when we say John Smith is the owner of Blackacre. True, there are similarities. Both the United States and Smith have the power and capacity to acquire, hold, and transfer the land. But the differences are substantial. Smith holds his property by virtue of local law; the United States hold lands by virtue of its own fiat. Smith's property is subject to involuntary loss through seizure for taxes, condemnation, adverse possession, or action by his creditors; the public domain can only be lost with the consent of Congress. The private owner can dispose of his land only within the franework of local law, but the Umited States enacts new laws at will. The United States mixes concepts of sovereignty with its proprietorship, and enacts criminal statutes for the special protection of the public domain, but Smith must look to local law to regulate conduct on his land. The title passed to Smith's grantees may differ from that of the patentee of the public domain.

It can thus readily be seen that government ownership is not the same as private ownership. At one time California made the mistake of thinking that "ownership" had an independent meaning, and ascribed ordinary traits of land ownership to the federal lands. For a time this made water law simply a matter of public land law. By assuming that the federal title carried with it the ordinary incidents of private land ownership, including riparian rights, and that an appropriation of water was a grant of water from the United States as the riparian proprietor, it followed that when the land was patented to an individual, he got the government's riparian rights subject only to previous grants of water. ${ }^{63}$ The relative rights of riparian owners and of appropriators were thus matters to be deduced fron the original federal ownership of land and water. ${ }^{64}$ Rather curiously, such federal riparian rights were denied by the Supreme Court, ${ }^{65}$ and it later held that no riparian rights attach until the land passed into private control..$^{60}$ In any case, such federal riparian rights would not be determinative of the question of federal "ownership" of the streams, even by a priori reasoning, for as above noted the riparian owner is never regarded as the owner of the corpus of the water.

Other states rejected this reasoning, holding that riparian rights never obtained in the arid west, so that the federal government never had any. ${ }^{07}$ Yet in so saying, the courts of these states have affirmed a true federal title

03 Conger v. Weaver, 6 Cal. 548 (1856).

64 San Joaquin \& Kings River Canal \& Irrigation Co. v. Worswick, 187 Cal. 674, 203 Pac. 999 (1922).

65 Atchison v. Peterson, 87 U.S. 507 (1874).

68 Sturr v. Beck, 133 U.S. 541 (1890).

${ }^{67}$ Coffin v. Left Hand Ditch Co., 6 Colo. 443 (1882); Moyer v. Preston, 6 Wyo. 308, 44 Pac. 845 (1896). 
to the streams, but only as an original proprietorship from which a state ownership can be derived. Some states deraign a state title to the waters of the streams by virtue of their constitutional declaration of state or public ownership, and the acts of admission which accepted the constitutions. ${ }^{68}$ Others ${ }^{69}$ trace their chain of title through the Desert Land Act ${ }^{70}$ by which Congress in 1877 declared the waters of non-navigable sources upon the public lands free for appropriation and use by the public, under state law, as the Supreme Court later held. ${ }^{71}$

By and large, the Supreme Court has never used property concepts in deciding water cases. The interstate suits have been based upon apportionment of water between individual users who are represented by their states in the controversy ${ }^{72}$ and while a sovereign interest in the prosperity of the lands watered by the river has been recognized ${ }^{73}$ the apportionment has been to the states as representatives, not as owners. In those cases in which state and federal interests-or state-based and federally-based interestshave conflicted, the Court has scrupulously based its decisions on the question of the allocation of sovereign power among the umits of a federated government. In United States v. Rio Grande Dam and Irrigation Co., ${ }^{74}$ the holding was that the federal government had superior power to protect the navigability of a river from state-authorized action. In California Oregon Power Co. v. Beaver Portland Cement Co. ${ }^{75}$ the Court construed the Desert Land Act as a recognition of the desirability of state control over water rights, as a local problem, and as a relinquishment to the states of whatever federal power existed because of the ownership of the public lands. In Winters $v$. United States, ${ }^{78}$ the question of the existence of a state power to curtail the obligations of the United States under a treaty with an Indian tribe was brushed aside. In the Pelton Dam case, ${ }^{77}$ the court held that a federally-hicensed power project on a non-navigable river, where the dam was situated on reserved lands, could not be blocked by state attempts to regulate the river in the interest of fish conservation.

In the Indian cases, ${ }^{78}$ Indians on reservations established by a treaty or executive order have rights to use water to the extent necessary for the ulti-

68 E.g., Merrill v. Bishop, 74 Wyo. 298, 287 P.2d 620 (1955).

69 E.g., State ex rel. Bliss v. Dority, 55 N.M. 12, 225 P.2d 1007 (1950).

7019 STAT. 377 (1877), 43 U.S.C. $\$ 321$ (1952).

71 California Oregon Power Co. v. Beaver Portland Cement Co., 295 U.S. 142 (1935).

22 E.g., Nebraska v. Wyoming, 325 U.S. 589 (1945); Wyoming v. Colorado, 259 U.S. 419 (1922).

73 Kansas v. Colorado, 206 U.S. 46 (1907).

74. 174 U.S. 690 (1899).

75295 U.S. 142 (1935).

TB 207 U.S. 564 (1908).

77 FPC v. Oregon, 349 U.S. 435 (1955).

78 E.g., Winters v. United States, 207 U.S. 564 (1908) ; United States v. Walker River Irrigation Dist., 104 F.2d 334 (1939). 
mate development of the reservation lands, although the waters have not been applied to beneficial use so as to amount to appropriations under state water laws, and although other persons have, prior to their use, made such appropriations. The large extent of federal withdrawals or reservations from the public domain has caused many to fear that if the principle of Indian water rights is extended to all such reserved parts of the public domain, water rights that have existed for many years will be endangered.

I do not believe that such conflicts, when they arise, as they surely will, can be or will be settled by concepts of "ownership," by examining the title of the federal government and the states, by interpreting the treaties, acts of congress, executive orders withdrawing lands, state constitutions, as if they were deeds in the abstract of title to a farm. Rather, there are two other questions here, one of the power of the federal government, and one of the appropriateness of the exercise of that power.

To date, there is no case, except for some of the Indian cases, ${ }^{70}$ that has directly involved a controversy over the conflicting federal and state claims to the consumptive use of an insufficient supply of water. Several types of such conflicts may arise.

Assume a non-navigable source of water, part of which flows through federal public domain, three-fourths of which is appropriated under state law. Suppose that today the Defense Department decides that the use of the land is necessary for an inter-continental ballistic missile launching site, for which all of the remaining water of the source is necessary. Yet suppose that state water authorities feel that the public interests of the state would be better served by the construction of an irrigation project elsewhere. Who will get the water, the Defense Department or the irrigation project?

Assume the same stream, except that the ICBM installation will need three-fourths of the water from the source. Without doubt, the Defense Department will eventually get the water, the users of one-half of the water under state law must give way to the requirements of the national government. Should the Defense Department simply take the water, by the exercise of what could be called a preference, without compensation, destroying the investments in value of the irrigated farms? Or should compensation be paid? Would it make a difference whether the withdrawal of the land was made in 1957 or in 1900 ?

Suppose the same stream, three-fourths of which is appropriated under the state law, and suppose that in its upper reaches the banks were reserved for a power site in 1909. The Federal Power Commission licenses a power plant, a dam is built in 1958. Can the power company withhold water from all irrigators with priorities junior to 1909?

I submit that these problems are not going to be decided under precon-

79 Note 78 supra. 
ceived notions of "ownership." First will come questions as to the warrant of the federal government under the war power and the property clause to take the water and use it for the benefit of the federal land in the furtherance of a national purpose. Next will come questions as to whether those powers ought to be exercised. For the Supreme Court has recognized, in California Oregon Power Co. v. Beaver Portland Cement Co. ${ }^{80}$ that "The public interest in such state control [of water resources] in the arid land states is definite and substantial." Although the powers of the national government, as presently construed, are extremely broad, questions continually arise as to whether these powers should be exercised as a matter of policy. As the Court said in United States v. Gerlach Live Stock Co., ${ }^{81}$ a federal public interest may require appropriation; it does not require expropriation. Careful consideration will be given to whether it is necessary or desirable to push national action to the limits of national power, or whether to leave the matters to the states. ${ }^{82}$ The extent to which the state control of water has in the past been recognized will play a part. In the early Statutes of 1866 and $1870,{ }^{83}$ the Desert Land Act, ${ }^{84}$ section 8 of the Reclamation Act, ${ }^{86}$ section 18 of the Boulder Canyon Project Act, ${ }^{86}$ section 1 of the Flood Control Act of $1944,{ }^{87}$ and in many others the right of the states to control water law has been recognized by Congress. The history of the development of the West, of the rehance of water users on state law, will play a greater part in the decisions than formal logic based on some "thing" called "ownership."

\section{CONCLUSTON}

Why then do we continue to use such words as "ownership"? We use them because they serve a very useful purpose, they convey our meaning. We usually mean by "state ownership" that in a crowded world the social interest in the use and conservation of the water resources has become more important than some individual interests ${ }^{88}$ We use them because they call into the mind of our hearers thoughts equivalent to our own, which is the very purpose of communication. This function of words has never been better expressed than in an earlier article which in part covered this same subject: $:^{80}$

80295 U.S. 142, 165 (1935).

81339 U.S. 725 (1950).

82 Anderson, The Nation and the States, Rtvais or Partners? 136 (1955).

83 Rev. Stat. \$ 2339 (1875), 30 U.S.C. \& 51 (1952); Rev. StaT. \$\$ 2339, 2340 (1875),

43 U.S.C. 8661 (1952).

8119 STAT. 377 (1877), 43 U.S.C. $\$ 321$ (1952).

8532 STAT. 390 (1902), 43 U.S.C. $\$ \$ 372,383$ (1952).

8645 StaT. 1065 (1928), 43 U.S.C. $\$ 617 q$ (1952).

8758 STaT. 887 (1944), 33 U.S.C. $\$ 701-1$ (1952).

88 See Pound, The End of Law, 27 Harv. L. Rev. 195, 234 (1914).

89 Lasky, From Prior Appropriation to Economic Distribution of Water, 1 Rockx MT. I.

REv. 161, 187 (1929). 
It may be that using the words 'state ownership' instead of 'the social interest in the conservation and economical use of natural resources' is only a quibble over phraseology. Yet words have a magic and may clarify or obscure an idea; we might as well say 'abracadabra' instead of 'alakazam' if the former conjures up a vista of development whereas the latter smokes up a fog of legal concepts laden with restrictions.

There is magic in causing our hearers to think what we think, to take our words in the sense we say them. But we do not create anything by this magic. It must always be reinembered that when we say "alakazam," or "state ownership," or "the state holds in trust," no genie out of a bottle brings us a beautiful maiden draped in pearls, and no magical solution is provided for difficult problems of adjusting the relations of an individual to the state or of the state to the federal government in the complex field of developinent of water resources. 